\title{
Race Characterization of Phytophthora Root Rot on Capsicum in Taiwan as a Basis for Anticipatory Resistance Breeding
}

\author{
Derek W. Barchenger, Zong-Ming Sheu, Sanjeet Kumar, Shih-Wen Lin, Rishi R. Burlakoti, and Paul W. Bosland ${ }^{\dagger}$
}

First and sixth authors: Department of Plant and Environmental Sciences, New Mexico State University, Las Cruces; and first, second, third, fourth, and fifth: World Vegetable Center, Shanhua, Tainan, Taiwan.

Current address of fifth author: Agassiz Research and Development Center, Agriculture and Agri-Food Canada, Agassiz, British Columbia, Canada.

Accepted for publication 24 February 2018.

\begin{abstract}
Peppers (Capsicum sp.) are an increasingly important crop because of their use as a vegetable, spice, and food colorant. The oomycete Phytophthora capsici is one of the most devastating pathogens to pepper production worldwide, causing more than $\$ 100$ million in losses annually. Developing cultivars resistant to $P$. capsici is challenging because of the many physiological races that exist and new races that are continuously evolving. This problem is confounded by the lack of a universal system of race characterization. As a basis to develop a global anticipatory breeding program, New Mexico recombinant inbred lines (NMRILs) functioned as a host differential for Phytophthora root rot to characterize the race structure of $P$. capsici populations in Taiwan. Using the NMRILs, 24 new

to be geographically specific and in two virulence clusters. Interestingly, all but two isolates collected in 2016 were the A2 mating type, which is a shift from the predominantly A1 mating type isolates collected prior to 2008 . The NMRILs host differential provides an approach for scientists to work together on a global scale when breeding for resistance as well as on a local level for regional gene deployment. Additionally, we propose that the current race numbering system, which has no biological meaning, be supplemented with the virulence phenotype, based on the susceptible NMRILs to a given isolate. This work provides insights into the population dynamics of $P$. capsici and interactions within the highly complex Capsicum-Phytophthora pathosystem, and offers a basis for similar research in other crops.
\end{abstract} races were identified, illustrating the utility and usefulness of the NMRILs for anticipatory breeding. Virulence of $P$. capsici was observed

Domesticated in the Americas, peppers (Capsicum sp.) are cultivated worldwide and have become a major food component in much of Africa, Asia, and Europe. Consumer demand for peppers worldwide has steadily increased over the last century (Crosby 2008), making them a viable cash crop. In addition, peppers have a high content of carotenoids that exhibit high provitamin A activity. Increased consumption of peppers can play a role in alleviating vitamin A deficiency. Thus, pepper production and consumption has the potential for short-term economic benefits for smallholder farmers (Lin et al. 2013) as well as long-term nutritional benefits for consumers, especially in underdeveloped countries.

One of the most devastating diseases of peppers worldwide is Phytophthora root rot caused by Phytophthora capsici (Leon.), resulting in an estimated annual loss exceeding $\$ 100$ million (Bosland 2008). Conditions of high soil moisture and high relative humidity are favorable for infection and disease development by P. capsici (Sanogo and Ji 2013). Current management practices for Phytophthora are largely cultural and chemical strategies, including planting resistant cultivars, irrigation management, and soil solarization, as well as fungicide applications (Granke et al. 2012; Hausbeck and Lamour 2004; Sanogo 2003). However, these strategies often result in insufficient control of the disease (Hausbeck

†Corresponding author: P. W. Bosland; E-mail: pbosland@nmsu.edu

Funding: This work was supported by the U.S. Borlaug Fellows in Global Food Security Program through Purdue University, funded by the United States Agency for International Development and New Mexico State University.

*The $\boldsymbol{e}$-Xtra logo stands for "electronic extra" and indicates that one supplementary table is published online.

(C) 2018 The American Phytopathological Society
Additional keywords: chile pepper, disease resistance, Phytophthora wilt.

and Lamour 2004). The oomycete pathogen also has a broad host range including several crop and weed species (Erwin and Riberio 1996; Granke et al. 2012). The development and use of resistant cultivars to $P$. capsici is the least expensive method and option to reduce fungicide applications and other management practices (Hausbeck and Lamour 2004).

Although resistant cultivars are currently used to limit losses associated with $P$. capsici, there is a continual need for more resistant cultivars because of several important challenges. First, $P$. capsici can infect all organs of pepper in all stages of growth, and for each disease phase (root rot, foliar blight, stem blight, and fruit rot) separate and independent resistance systems have evolved in the host (Monroy-Barbosa and Bosland 2010), requiring the presence of specific resistance $(R)$ loci (Sy et al. 2005). Second, breeding for $P$. capsici resistance in pepper is challenging because new races are continually evolving that can overcome the host resistance (Boutemy et al. 2011). Multiple physiological races of $P$. capsici have been identified for root rot and foliar blight (Glosier et al. 2008; Jiang et al. 2015; Monroy-Barbosa and Bosland 2010; Sy et al. 2008), and different $R$ genes control the resistant phenotype against different physiological races of $P$. capsici within each disease phase (Monroy-Barbosa and Bosland 2008). The high level of diversity found in $P$. capsici has been attributed to sexual reproduction, when A1 and A2 mating types are present in the same field (Jiang et al. 2015; Lamour and Hausbeck 2002; Sheu et al. 2009), mutation, and loss of heterozygosity (Dunn et al. 2014; Lamour et al. 2012). Of the disease phases, root rot is the most devastating to pepper worldwide. Sources for $P$. capsici resistance have been identified in C. annuum, such as Criollo de Morelos-334 (CM334), PI 201232 and PI 201234 from Mexico, AC2258 from Central America, and cultivar Perennial from India. Among the sources of resistance, CM334 has the highest resistance level (Quirin et al. 2005) to all phases of P. capsici. 
The Capsicum-Phytophthora pathosystem is more complex than initially thought and breeding approaches that incorporate more diverse germplasm and emerging sequencing techniques must be employed for local as well as global success in breeding for resistance.

Several approaches are in place to aid breeders working with pathogen resistance in plants. One such approach is anticipatory breeding, a method of breeding for resistance to virulent pathogen races before they become prevalent and cause significant losses (McIntosh 1992; McIntosh and Brown 1997). Successful anticipatory breeding requires knowledge of pathogen epidemiology, regular pathogen surveys aimed at detecting new races that have the potential to overcome current $R$ genes, knowledge of primary $R$ genes in current cultivars, and a well-coordinated system of screening for identifying sources of resistance. Anticipatory breeding is a vital tool in breeding for disease resistance because it gives breeders an advantage over the pathogen by using prediction models to preemptively select for resistance against novel races.

Phenotypic and genotypic diversity of $P$. capsici has been studied in important pepper growing regions around the world (Black and Berke 1998; Castro-Rocha et al. 2016; Gniffke et al. 2013; Gobena et al. 2012; Hulvey et al. 2011; Hurtado-Gonzales et al. 2008; Lamour and Hausbeck 2001; Meitz et al. 2010; Oelke et al. 2003; Sheu et al. 2004; Silvar et al. 2006; Sun et al. 2008). However, there is no standardized and widely adopted system for $P$. capsici race characterization (Glosier et al. 2008). Commonly, pathogen races are characterized utilizing a set of host differentials consisting of accessions that are made up of cultivars, varieties, and related species having one or more resistance genes to a pathogen (Stakman et al. 1962). A limitation to this approach is that cultivars can become unavailable, and not all accessions are available to all scientists worldwide. Unlike other crops (McIntosh 1992; McIntosh and Brown 1997), the use of pepper cultivars can be difficult for race detection because cultivars can vary among seed companies and can segregate (Candole et al. 2012; Votava and Bosland 2002). Recombinant inbred lines (RILs) are often used as host differentials to identify races of pathogens (Lister and Dean 1993). The RILs allow the maximum genetic variability within a population with homozygous genotypes that can be replicated permanently without the risk of segregation occurring. Sy et al. (2008) developed a differential set of New Mexico recombinant inbred lines (NMRILs) for $P$. capsici race characterization that has the potential to be a model for large scale anticipatory breeding systems for resistance in pepper. In addition to wide service in New Mexico (Jiang et al. 2015; Monroy-Barbosa and Bosland 2008, 2010, 2011; Sy et al. 2008), the NMRILs have been used to assist in race characterization of P. capsici isolated from pepper and other species in Brazil (da Costa Ribeiro and Bosland 2012). The NMRILs have the potential to be more widely used, especially in important pepper growing areas in Asia and Africa where $P$. capsici is a major production constraint (Meitz et al. 2010). In addition, the RILs can have utility in identifying other fungal and oomycete pathogen resistance, not only P. capsici (Naegele et al. 2017). Here, we explored the use of NMRILs as an anticipatory resistance breeding tool applied to $P$. capsici in Taiwan and recommend the use of a supplemental race nomenclature system.

\section{MATERIALS AND METHODS}

Pathogen isolation and culture. Isolates of $P$. capsici were collected from important chile pepper and sweet pepper growing areas of Taiwan during the summer season in 2016 (Table 1). The majority of pepper production occurs in the lowlands of Taiwan during the fall/winter season; however, $P$. capsici is more prevalent during the summer season when environmental conditions are more favorable. Plants with symptoms of root rot and stem blight were collected from fields and immediately placed on ice until isolation, which occurred 1 to 3 days after collection. Plants were sampled based on where the disease symptoms were observed within a field and only one isolate was retained per plant. For stem isolation, the epidermis was removed from the border region between the symptomatic (dark in color and sunken) and nonsymptomatic tissue, and 8 to 10 pieces of cortical tissue $\approx 4 \mathrm{~mm}^{2}$ in size were extracted. For root isolation, $0.2-\mathrm{cm}$-long pieces of small secondary roots at the border between symptomatic and nonsymptomatic tissue were excised. The stem and root pieces were surface-disinfested in a $1 \%$ $\mathrm{NaClO}$ solution for $30 \mathrm{~s}$, rinsed for a few seconds in sterile deionized distilled water $\left(\mathrm{ddH}_{2} 0\right)$, and air-dried on sterilized filter paper. The pieces of surface-disinfested tissue were then plated on V8 agar medium amended with ampicillin (100 mg/liter), nystatin ( $100 \mathrm{mg} / \mathrm{liter})$, and rifampicin $(50 \mathrm{mg} / \mathrm{liter})$ at $28^{\circ} \mathrm{C}$ for 2 to 3 days in the dark. The plates were then visually inspected, and $7 \mathrm{~mm}$ plugs were transferred onto potato dextrose agar (PDA) plates (Tuite 1969). Cultures were identified to species on the basis of petaloid to rosaceous colony morphology and ovoid, papillate sporangia borne on long pedicels and aseptate hypha (Leonian 1922). Cultures were purified by single-zoospore isolation (Ho and Ko 1997) and isolates were maintained on PDA slants under sterilized mineral oil at $20^{\circ} \mathrm{C}$.

Species identification by $\boldsymbol{P}$. capsici-specific PCR. Each single zoospore derived isolate was grown on V8 agar for approximately 7 days and then one $7 \mathrm{~mm}$ plug was transferred to $80 \mathrm{ml}$ of potato dextrose broth (PDB) and incubated at $28^{\circ} \mathrm{C}$ for 4 to 7 days. Mycelial-mats were filtered out of the solution using a vacuum onto sterilized filter paper, rinsed with $\mathrm{ddH}_{2} \mathrm{O}$ three times, and then dried at room temperature for $5 \mathrm{~h}$. The dried mycelium mats were then moved to $-20^{\circ} \mathrm{C}$ overnight and transferred to liquid nitrogen prior to DNA isolation. DNA was extracted using the Qiagen DNeasy Plant Mini Kit (Qiagen, Hilden, Germany) according to the manufacturer guidelines with minor modifications. Briefly, the elution time was extended to $10 \mathrm{~min}$ and mycelium was disrupted using a mini beadbeater (Biospec Products Inc., Bartlesville) for $60 \mathrm{~s}$. Total DNA quality was evaluated using a spectrophotometer and visualized on a $0.8 \%$ agarose gel stained with ethidium bromide using UVITEC Imaging Systems (Cleaver Scientific, Warwickshire, UK) prior to PCR.

The species-specific primers Pc3 and Pc6R (Zhang et al. 2008) as well as CAPFW and CAPRV2 (Silvar et al. 2005) were used to confirm that the isolates were P. capsici. The modified PCR of Dunn et al. (2010) and Silvar et al. (2005) were followed. The thermocycler reaction included an initial incubation at $95^{\circ} \mathrm{C}$ for $10 \mathrm{~min}$, followed by 35 cycles of denaturation at $95^{\circ} \mathrm{C}$ for $30 \mathrm{~s}$, annealing at $58^{\circ} \mathrm{C}$ for $45 \mathrm{~s}$, and extension at $72^{\circ} \mathrm{C}$ for $45 \mathrm{~s}$ and a final extension step for $10 \mathrm{~min}$ at $72^{\circ} \mathrm{C}$. The amplicons were visualized on an $8 \%$ polyacrylamide gel stained with ethidium bromide using UVITEC Imaging Systems (Cleaver Scientific). Negative controls containing no genomic DNA were included to check for contaminated reagents, DNA from confirmed $P$. infestans (Mont.) and $P$. melonis (Katsura) isolates were also used, and DNA from known $P$. capsici isolates from Taiwan were included as positive controls (Dunn et al. 2010).

Determination of mating type. To determine mating type, a $7 \mathrm{~mm}$ plug of each isolate was cocultured onto V8 agar medium with isolates of known mating types A1 (Pc134) and A2 (Pc282). Both of these controls were isolated from sweet pepper in Nantou County in the Central region of Taiwan, Pc134 was collected in 2004 and Pc282 in 2009. Petri dishes were incubated at $28^{\circ} \mathrm{C}$ for 6 days and then oospore production was observed using a microscope. Isolates producing oospores with one of the isolates with a known mating type and not the other, were identified as being of the opposite mating type. To ensure correct identification, the mating type experiment was repeated.

Plant materials. For host differentials, 18 NMRILs (Sy et al. 2008) were used. The Mexican landrace CM334 was the negative control (resistant) and New Mexico Capsicum Accession 10399 (NMCA10399) was the positive control (susceptible). If CM334 
showed any symptoms whatsoever, it was assumed that there was contamination from another pathogen. Similarity, if NMCA10399 was asymptomatic, we assumed that there was no viable inoculum used in the experiment. Two seeds per cell were sown into 72 cell plastic trays filled with sterilized peat moss and plants were later thinned to one plant per cell. Trays were placed in a climate controlled greenhouse maintained at $28 \pm 3^{\circ} \mathrm{C}$ with a 12 -h photoperiod and $\approx 95 \%$ relative humidity. Plants were hand irrigated twice daily during the experimental period. Two weeks after sowing, seedlings were fertilized with Nitrophoska (20-19-19).

Inoculations and phenotyping of host differentials. The 24 isolates collected in 2016 as well as the previously collected WorldVeg race 1 (Pc1E8), 2 (Pc33), and 3 (Pc134) (Black 1999) were used for NMRIL screening (Table 1). According to Black (1999) Pc1E8, Pc33, and Pc134 were identified as race 1, 2, and 3, respectively, based on disease reactions on cultivar Early CalWonder, PBC 137, PBC 602, and PI 201234.

The isolates were transferred from oil culture onto V8 agar 7 days prior to subculture. All isolates were subcultured onto V8 agar plates at $28^{\circ} \mathrm{C}$ for 4 days (three $7 \mathrm{~mm}$ plugs per plate). The cultures were then cut into $\approx 1 \mathrm{~cm}^{2}$ pieces and soaked in $\mathrm{ddH}_{2} 0$ for $1 \mathrm{~h}$ at room temperature. The $\mathrm{ddH}_{2} \mathrm{O}$ was then removed by vacuum and
$\mathrm{ddH}_{2} \mathrm{O}$ was added back to each plate, and the cultures were incubated at $28^{\circ} \mathrm{C}$ with continuous fluorescent light overnight. The next day, the flooded cultures were then incubated in darkness at $4^{\circ} \mathrm{C}$ for $1 \mathrm{~h}$ and then $1 \mathrm{~h}$ at room temperature $\left(\approx 24^{\circ} \mathrm{C}\right)$ for zoospore release. The zoospores were collected and quantified using a hemacytometer. Inoculum was diluted to $2 \times 10^{3} \mathrm{ml}^{-1}$ (Sy et al. 2008). Each plant received $5 \mathrm{ml}$ of inoculum for a final concentration of $1 \times 10^{4}$ plant $^{-1}$ as a drench. All plants were hand watered twice daily to maintain media saturation during the 2 weeks of the inoculation experiment. Seedlings were inoculated 4 weeks after planting at the four to six true leaf stage (Bosland and Lindsey 1991). Treatments were arranged on greenhouse benches in a completely randomized design. Experimental units consisted of six plants with two replications per isolate, and the experiment was repeated once. Plants were scored 13 to 18 days after inoculation when the susceptible control (NMCA10399) displayed extreme root-rot symptoms. A standardized 10-point interaction phenotype scale was used (Fig. 1) for scoring (Bosland and Lindsey 1991), where $0=$ no response, vigorous and healthy; 1 = slight root darkening, vigorous, and healthy; 3 = brown roots, slight stunting, very small lesions on stems; 5 = brown roots, small lesions on stems; 7 = brown roots, large lesions on stems, girdling, whole plant wilted and stunted; and

TABLE 1. Summary data of Phytophthora capsici isolates from Taiwan used in this experiment

\begin{tabular}{|c|c|c|c|c|c|c|c|c|c|}
\hline \multirow{2}{*}{$\frac{\text { Isolate }^{a}}{\text { Pc1E8 }}$} & \multirow{2}{*}{$\frac{\text { Date isolated }^{\mathrm{b}}}{6-\mathrm{Jul}-87}$} & \multirow{2}{*}{$\frac{\operatorname{Host}^{\mathrm{c}}}{\mathrm{S}}$} & \multirow{2}{*}{$\begin{array}{l}\text { Tissue } \\
\text { Stem }\end{array}$} & \multirow{2}{*}{$\frac{\text { County }}{\text { Taipei }}$} & \multirow{2}{*}{$\frac{\text { Township }}{\text { Yangmingshan }}$} & \multirow{2}{*}{$\frac{\text { Region }^{\mathrm{d}}}{\mathrm{N}}$} & \multicolumn{2}{|c|}{ GPS coordinates } & \multirow{2}{*}{$\frac{\text { Mating type }}{\text { A1 }}$} \\
\hline & & & & & & & $\ldots e^{e}$ & $\ldots$ & \\
\hline Pc33 & 1-Jul-95 & $\mathrm{C}$ & Stem & Tainan & Shanhua & $\mathrm{S}$ & $\ldots$ & $\ldots$ & A1 \\
\hline Pc134 & 2-Jun-04 & $\mathrm{S}$ & Stem & Nantou & Hsinyi & $\mathrm{C}$ & $\ldots$ & $\ldots$ & A1 \\
\hline Pc373 & 19-May & $\mathrm{C}$ & Stem & Chiayi & Lucao & $\mathrm{S}$ & $23.4^{\circ} \mathrm{N}$ & $120.3^{\circ} \mathrm{E}$ & $\mathrm{A} 2$ \\
\hline Pc374 & 19-May & $\mathrm{C}$ & Root & Chiayi & Lucao & $\mathrm{S}$ & $23.4^{\circ} \mathrm{N}$ & $120.3^{\circ} \mathrm{E}$ & $\mathrm{A} 2$ \\
\hline Pc375 & 19-May & $\mathrm{S}$ & Stem & Yunlin & Chitong & $\mathrm{C}$ & $23.7^{\circ} \mathrm{N}$ & $120.5^{\circ} \mathrm{E}$ & $\mathrm{A} 2$ \\
\hline Pc376 & 19-May & $\mathrm{S}$ & Root & Yunlin & Chitong & $\mathrm{C}$ & $23.7^{\circ} \mathrm{N}$ & $120.5^{\circ} \mathrm{E}$ & $\mathrm{A} 2$ \\
\hline Pc377 & 19-May & $\mathrm{S}$ & Stem & Yunlin & Siluo & $\mathrm{C}$ & $23.8^{\circ} \mathrm{N}$ & $120.5^{\circ} \mathrm{E}$ & A2 \\
\hline Pc378 & 19-May & $\mathrm{S}$ & Root & Yunlin & Siluo & $\mathrm{C}$ & $23.8^{\circ} \mathrm{N}$ & $120.5^{\circ} \mathrm{E}$ & $\mathrm{A} 2$ \\
\hline Pc379 & 31-May & $\mathrm{S}$ & Stem & Yunlin & Linnei & $\mathrm{C}$ & $23.8^{\circ} \mathrm{N}$ & $120.6^{\circ} \mathrm{E}$ & A1 \\
\hline Pc380 & 31-May & $\mathrm{S}$ & Root & Yunlin & Linnei & $\mathrm{C}$ & $23.8^{\circ} \mathrm{N}$ & $120.6^{\circ} \mathrm{E}$ & $\mathrm{A} 2$ \\
\hline Pc381 & 31-May & $\mathrm{S}$ & Root & Yunlin & Linnei & $\mathrm{C}$ & $23.8^{\circ} \mathrm{N}$ & $120.6^{\circ} \mathrm{E}$ & A1 \\
\hline Pc382 & 7-Jun & $\mathrm{C}$ & Stem & Pingtung & Gaoshu & $\mathrm{S}$ & $22.9^{\circ} \mathrm{N}$ & $120.6^{\circ} \mathrm{E}$ & $\mathrm{A} 2$ \\
\hline Pc383 & 7-Jun & $\mathrm{C}$ & Root & Pingtung & Gaoshu & $\mathrm{S}$ & $22.9^{\circ} \mathrm{N}$ & $120.6^{\circ} \mathrm{E}$ & $\mathrm{A} 2$ \\
\hline Pc384 & 7-Jun & $\mathrm{C}$ & Stem & Kaohsiung & Meinong & $\mathrm{S}$ & $22.9^{\circ} \mathrm{N}$ & $120.6^{\circ} \mathrm{E}$ & $\mathrm{A} 2$ \\
\hline Pc385 & 7-Jun & $\mathrm{C}$ & Root & Kaohsiung & Meinong & $\mathrm{S}$ & $22.9^{\circ} \mathrm{N}$ & $120.6^{\circ} \mathrm{E}$ & $\mathrm{A} 2$ \\
\hline Pc388 & 4-Jul & $\mathrm{C}$ & Stem & Taitung & Luye & $\mathrm{E}$ & $22.9^{\circ} \mathrm{N}$ & $121.1^{\circ} \mathrm{E}$ & A2 \\
\hline Pc389 & 5-Jul & $\mathrm{S}$ & Fruit & Hualien & Jian & $\mathrm{E}$ & $24.0^{\circ} \mathrm{N}$ & $121.6^{\circ} \mathrm{E}$ & $\mathrm{A} 2$ \\
\hline Pc390 & 4-Jul & $\mathrm{C}$ & Stem & Taitung & Guanshan & $\mathrm{E}$ & $23.0^{\circ} \mathrm{N}$ & $121.1^{\circ} \mathrm{E}$ & A 2 \\
\hline Pc391 & 4-Jul & $\mathrm{C}$ & Root & Taitung & Guanshan & $\mathrm{E}$ & $23.0^{\circ} \mathrm{N}$ & $121.1^{\circ} \mathrm{E}$ & $\mathrm{A} 2$ \\
\hline Pc392 & 5-Jul & $\mathrm{S}$ & Stem & Hualien & Jian & $\mathrm{E}$ & $24.0^{\circ} \mathrm{N}$ & $121.6^{\circ} \mathrm{E}$ & $\mathrm{A} 2$ \\
\hline Pc393 & 5-Jul & $\mathrm{S}$ & Root & Hualien & Jian & $\mathrm{E}$ & $24.0^{\circ} \mathrm{N}$ & $121.6^{\circ} \mathrm{E}$ & $\mathrm{A} 2$ \\
\hline Pc394 & 5-Jul & $\mathrm{S}$ & Stem & Hualien & Jian & $\mathrm{E}$ & $24.0^{\circ} \mathrm{N}$ & $121.6^{\circ} \mathrm{E}$ & $\mathrm{A} 2$ \\
\hline Pc395 & 5-Jul & $\mathrm{S}$ & Stem & Hualien & Shoufong & $\mathrm{E}$ & $23.8^{\circ} \mathrm{N}$ & $121.5^{\circ} \mathrm{E}$ & $\mathrm{A} 2$ \\
\hline Pc396 & 5-Jul & $\mathrm{S}$ & Stem & Hualien & Jian & $\mathrm{E}$ & $24.0^{\circ} \mathrm{N}$ & $121.6^{\circ} \mathrm{E}$ & $\mathrm{A} 2$ \\
\hline Pc397 & 4-Jul & $\mathrm{C}$ & Root & Taitung & Luye & $\mathrm{E}$ & $22.9^{\circ} \mathrm{N}$ & $121.1^{\circ} \mathrm{E}$ & A2 \\
\hline Pc398 & 5-Jul & $\mathrm{S}$ & Root & Hualien & Jian & $\mathrm{E}$ & $24.0^{\circ} \mathrm{N}$ & $121.6^{\circ} \mathrm{E}$ & $\mathrm{A} 2$ \\
\hline Pc399 & 5-Jul & $\mathrm{S}$ & Root & Hualien & Jian & $\mathrm{E}$ & $24.0^{\circ} \mathrm{N}$ & $121.6^{\circ} \mathrm{E}$ & $\mathrm{A} 2$ \\
\hline $\operatorname{Pc} 400$ & 5-Jul & $\mathrm{S}$ & Stem & Hualien & Jian & $\mathrm{E}$ & $24.0^{\circ} \mathrm{N}$ & $121.6^{\circ} \mathrm{E}$ & A 2 \\
\hline Pc401 & 5-Jul & $\mathrm{S}$ & Root & Hualien & Jian & $\mathrm{E}$ & $24.0^{\circ} \mathrm{N}$ & $121.6^{\circ} \mathrm{E}$ & $\mathrm{A} 2$ \\
\hline Pc402 & 5-Jul & $\mathrm{S}$ & Root & Hualien & Jian & $\mathrm{E}$ & $24.0^{\circ} \mathrm{N}$ & $121.6^{\circ} \mathrm{E}$ & $\mathrm{A} 2$ \\
\hline Pc403 & 5-Jul & $\mathrm{S}$ & Root & Hualien & Jian & $\mathrm{E}$ & $24.0^{\circ} \mathrm{N}$ & $121.6^{\circ} \mathrm{E}$ & $\mathrm{A} 2$ \\
\hline Pc404 & 5-Jul & $\mathrm{S}$ & Stem & Hualien & Jian & $\mathrm{E}$ & $24.0^{\circ} \mathrm{N}$ & $121.6^{\circ} \mathrm{E}$ & $\mathrm{A} 2$ \\
\hline Pc405 & 5-Jul & $\mathrm{S}$ & Stem & Hualien & Jian & $\mathrm{E}$ & $24.0^{\circ} \mathrm{N}$ & $121.6^{\circ} \mathrm{E}$ & $\mathrm{A} 2$ \\
\hline Pc406 & 5-Jul & $\mathrm{S}$ & Stem & Hualien & Jian & $\mathrm{E}$ & $24.0^{\circ} \mathrm{N}$ & $121.6^{\circ} \mathrm{E}$ & $\mathrm{A} 2$ \\
\hline Pc407 & 27-Jul & $\mathrm{S}$ & Root & Nantou & Hsinyi & $\mathrm{C}$ & $23.6^{\circ} \mathrm{N}$ & $120.9^{\circ} \mathrm{E}$ & $\mathrm{A} 2$ \\
\hline Pc408 & 27-Jul & $\mathrm{S}$ & Stem & Nantou & Hsinyi & $\mathrm{C}$ & $23.6^{\circ} \mathrm{N}$ & $120.9^{\circ} \mathrm{E}$ & $\mathrm{A} 2$ \\
\hline Pc409 & 27-Jul & $\mathrm{S}$ & Stem & Nantou & Hsinyi & $\mathrm{C}$ & $23.6^{\circ} \mathrm{N}$ & $120.9^{\circ} \mathrm{E}$ & A 2 \\
\hline Pc410 & 27-Jul & $\mathrm{S}$ & Stem & Nantou & Hsinyi & $\mathrm{C}$ & $23.6^{\circ} \mathrm{N}$ & $120.9^{\circ} \mathrm{E}$ & $\mathrm{A} 2$ \\
\hline Pc411 & 27-Jul & $\mathrm{S}$ & Root & Nantou & Hsinyi & $\mathrm{C}$ & $23.6^{\circ} \mathrm{N}$ & $120.9^{\circ} \mathrm{E}$ & $\mathrm{A} 2$ \\
\hline Pc413 & 10-Aug & $\mathrm{C}$ & Stem & Nantou & Renai & $\mathrm{C}$ & $23.9^{\circ} \mathrm{N}$ & $121.1^{\circ} \mathrm{E}$ & A2 \\
\hline
\end{tabular}

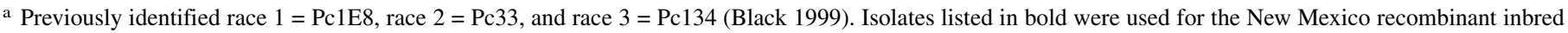
line screening experiment.

b All isolates were collected in 2016 unless otherwise indicated.

c $\mathrm{S}=$ sweet pepper, and $\mathrm{C}=$ chile pepper.

d $\mathrm{N}=$ Northern, $\mathrm{S}=$ Southern, $\mathrm{C}=$ Central, and $\mathrm{E}=$ Eastern.

e Data not available. 
9 = complete plant death (Fig. 1). Even numbers were used for intermediate responses. Plants with no root lesions were considered resistant (average score of $\leq 1$ ) and plants with symptoms ranging from very small root lesions to complete death were considered susceptible (average score of $>1$ ), because it has been observed that plants with even small root lesions will eventually die (Sy et al. 2008). Data were averaged within a replication and experiment for analysis. Phenotypic data of the average ratings of six plants within a replicate were analyzed using the nonparametric Kruskal-Wallis rank sum test (Shah and Madden 2004) with Dunn's test for multiple comparisons in $\mathrm{R}$ (version 3.3.1). Comparisons were made between average score and isolate, accession, isolation county, and isolation tissue, experiment, and replication. Based on the post hoc testing, scores among and within replications and experimental repetitions for all accession and isolate combinations were within a similar enough range to be considered an identical score (resistant or susceptible), which is justification for combining data between all experimental replications. An unweighted pair group method with arithmetic mean analysis (UPGMA) based on the binary data from the disease reaction, where resistant $=0$ and susceptible $=1$. The binary data from the entire experiment was used to calculate the similarity by the simple matching (SM) method and the tree (data not shown) was constructed through the SHAN program using the NTSYS software (version 2.2).

\section{RESULTS}

Pathogen collection and characterization. During the summer season (May to August) of 2016, 38 isolates of $P$. capsici from important pepper growing regions of Taiwan were collected and their cultures were successfully established at the World Vegetable Center (WorldVeg) (Table 1). The collection contained a total of 19 isolates from the Eastern region (15 from Hualien and 4 from Taitung counties), 13 from the Central region ( 7 isolates from Yunlin County and 6 from Nantou County), and 6 isolates from the Southern region (2 isolates each from Chiayi, Kaohsiung, and Pingtung counties).

The isolates collected in 2016 originated from different plant tissues: 20 isolates were from stem tissue, 17 were from root tissue, and 1 isolate was from fruit. The isolates Pc379 and Pc381 were the only two A1 mating type isolates collected in 2016. Both A1 mating type isolates were collected in the same field in the Linnei township, Yunlin County in the Central region of Taiwan; however, Pc379 was from stem tissue, while Pc381 was from root tissue. The A1 isolates were collected in the same field as the A2 isolate Pc380. The origin of the isolates included: 23 from green bell pepper, 4 from colored bell, and 11 from chile pepper. Successful amplification of every isolate was accomplished using the species-specific PCR assays with 219 (Zhang et al. 2008) and 595 bp (Silvar et al. 2005) amplicons, respectively.

Differential disease reaction. Although 38 isolates were collected, a representative 24 isolates were used for screening in addition to previously identified race 1 (Pc33E8), race 2 (Pc33), and race 3 (Pc134) (Black 1999) from the WorldVeg collection, due to time and greenhouse space constraints. The Kruskal-Wallis rank sum test indicated the disease severity score was significantly influenced by the main effects of isolate, accession, county, and tissue $(P<0.001$ for all effects $)$, while experiment $(P=0.8818)$ and replication $(P=0.6488)$ were not statistically significant.

The disease reaction results are presented in Table 2. Every isolate screened was virulent to the positive control NMCA10399, demonstrating that all collected isolates were in fact virulent. As expected, the negative control CM334 was resistant when challenged by all of the isolates. Additionally, each isolate was able to cause root rot symptoms on at least one of the NMRILs. Only symptoms typical of $P$. capsici infection (Leonian 1922) were observed in this experiment. Using the 18 NMRILs, 27 races from Taiwan were identified, each with a different virulence phenotype. These included the three races that had already been identified by WorldVeg, as well as 24 new races within the isolates collected in the summer of 2016.

Different levels of aggressiveness were observed among the isolates screened. For instance, Pc378 was the most virulent isolate with only four NMRILs having resistance. Pc390 and Pc397 were the least virulent isolates, with 16 NMRILs showing resistance. The isolates that were collected from root tissue were more virulent, with an average disease rating of 1.8, than those isolates from stem tissue, with an average disease rating of 1.5. Because only a single isolate was isolated from fruit, it was not included in the analysis. NMRIL-P and NMRIL-O were the most resistant lines, being susceptible to one (Pc134) and two isolates (Pc379 and Pc391), respectively. NMRIL-A, NMRIL-R, and NMRIL-S were the least resistant lines, each being susceptible to 21 isolates. Of the 18 NMRILs that were challenged with the $P$. capsici isolates, 10 were sufficient to serve as a host differential for the Taiwan isolates, with differing disease reactions for each isolate (Table 3).

Based on the phenotypic disease reactions, two main virulence clusters within the Taiwan isolates were identified through UPGMA (Table 3). The more virulent cluster was designated "Cluster 1" and the less virulent cluster as "Cluster 2." Within Cluster $1,54 \%$ of the isolates were collected in Yunlin County, which is in the Central region of Taiwan. Similarly, $64 \%$ of the Cluster 2 isolates were collected in the east coast counties of Hualien and Taitung. Isolates from the counties of Chiayi, Hualien, Kaohsiung, Nantou, and Pingtung were in both Cluster 1 and 2, while isolates from Yunlin County were only in Cluster 1 and isolates from Taitung County were only in Cluster 2. Dunn's test of multiple comparisons was used for pairwise comparisons of average isolate virulence among collection counties. The counties of Yunlin, Nantou, Chiayi, and Tainan were generally more virulent than those from Pingtung Hualien, Kaohsiung, Taitung, and Taipei counties (Fig. 2).

\section{DISCUSSION}

This study is the first report of race detection in Taiwan based on the NMRILs. Using a set of 18 NMRILs as a host differential, 27 races of $P$. capsici collected in Taiwan were phenotypically differentiated, 24 of which were previously unidentified, each with different virulence phenotypes. The identification of a high number

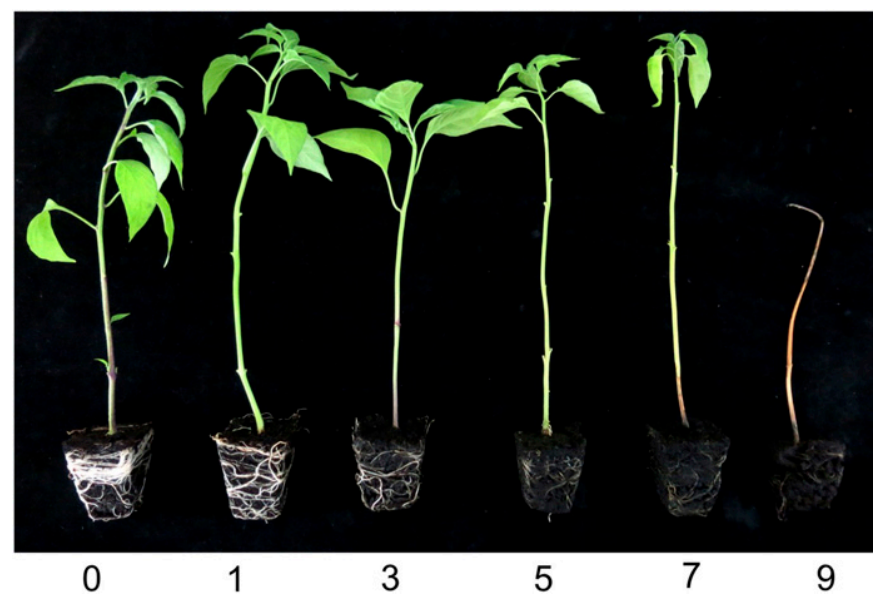

Fig. 1. Standardized rating scale used for scoring plants 2 weeks after inoculation with Phytophthora capsici, where $0=$ no response, vigorous and healthy; 1 = slight root darkening, vigorous, and healthy; 3 = brown roots, slight stunting, very small lesions on stems; $5=$ brown roots, small lesions on stems; 7 = brown roots, large lesions on stems, girdling, whole plant wilted and stunted; and $9=$ complete plant death. Even numbers were used for intermediate responses and are not shown. 
of races was also reported by recent work of Jiang et al. (2015) who screened 13 isolates and identified 12 different races using the NMRILs. However, older studies using the NMRILs found fewer novel races among the isolates screened. da Costa Ribeiro and Bosland (2012) identified 8 new races out of 20 isolates from Brazil, while Sy et al. (2008) identified 13 new races out of 17 isolates screened from New Mexico. Resistance is epistatic, and having one resistant/avirulence match-up gives the plant resistance.

A subset of 10 NMRILs could efficiently detect the novel races in Taiwan. Using a subset will allow for more efficient race detection in the future, as fewer plants are necessary to maintain and score. The total number of 76 NMRILs will be able to identify more than $7.6 \times 10^{22}$ races, and different subsets can be selected to aid in identification of the races in a region as the pathogen evolves. Although identification of a subset can be cumbersome, the advantage of this system is the use of a universal naming system supplemented with a virulent phenotype based on the resistant reactions to the NMRILs. Previous attempts at race characterization have used cultivars (Black 1999; Glosier et al. 2008; Oelke et al. 2003) that has limitations because pepper cultivars vary among seed companies and can segregate (Candole et al. 2012; Votava and Bosland 2002). The NMRILs provide a highly repeatable race characterization system, without the risk of segregation or variability. Furthermore, as greater knowledge of the targets in pepper to pathogen effectors becomes available, regional gene deployment will be possible based on the disease reactions using the NMRILs.

The majority (95\%) of the isolates collected in this study were A2 mating type. The first report of P. capsici in Taiwan was an A1 mating type in 1976 (Ann et al. 2008). Since the initial identification, a shift has been observed and the majority of the isolates collected in Taiwan over the past eight years have been the A2 mating type (Sheu et al. 2009). It is possible that this shift from A1 to A2 mating type could be associated with a genetic bottleneck. Additionally, an introduction event in 2008 that could be the source of the A2 mating type on the island cannot be ruled out. Similar to the findings reported here, the presence of both A1 and A2 mating types in a single field in Taiwan also has been observed (Sheu et al. 2009). The

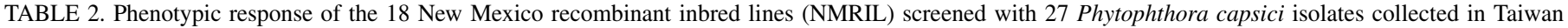

\begin{tabular}{|c|c|c|c|c|c|c|c|c|c|c|c|c|c|c|c|c|c|c|c|c|c|c|c|c|c|c|c|}
\hline \multirow[b]{2}{*}{ Accession } & \multicolumn{27}{|c|}{ Isolate $^{\mathrm{a}}$} \\
\hline & 378 & 374 & 376 & 134 & 379 & 33 & 381 & 383 & 375 & 385 & 380 & 398 & 377 & 373 & 393 & $1 \mathrm{E} 8$ & 395 & 389 & 382 & 384 & 396 & 388 & 391 & 392 & 413 & 390 & 397 \\
\hline CM $334^{\mathrm{b}}$ & $\mathrm{R}^{\mathrm{c}}$ & $\mathrm{R}$ & $\mathrm{R}$ & $\mathrm{R}$ & $\mathrm{R}$ & $\mathrm{R}$ & $\mathrm{R}$ & $\mathrm{R}$ & $\mathrm{R}$ & $\mathrm{R}$ & $\mathrm{R}$ & $\mathrm{R}$ & $\mathrm{R}$ & $\mathrm{R}$ & $\mathrm{R}$ & $\mathrm{R}$ & $\mathrm{R}$ & $\mathrm{R}$ & $\mathrm{R}$ & $\mathrm{R}$ & $\mathrm{R}$ & $\mathrm{R}$ & $\mathrm{R}$ & $\mathrm{R}$ & $\mathrm{R}$ & $\mathrm{R}$ & $\mathrm{R}$ \\
\hline NMRIL-P & $\mathrm{R}$ & $\mathrm{R}$ & $\mathrm{R}$ & $\mathrm{S}$ & $\mathrm{R}$ & $\mathrm{R}$ & $\mathrm{R}$ & $\mathrm{R}$ & $\mathrm{R}$ & $\mathrm{R}$ & $\mathrm{R}$ & $\mathrm{R}$ & $\mathrm{R}$ & $\mathrm{R}$ & $\mathrm{R}$ & $\mathrm{R}$ & $\mathrm{R}$ & $\mathrm{R}$ & $\mathrm{R}$ & $\mathrm{R}$ & $\mathrm{R}$ & $\mathrm{R}$ & $\mathrm{R}$ & $\mathrm{R}$ & $\mathrm{R}$ & $\mathrm{R}$ & $\mathrm{R}$ \\
\hline NMRIL-O & $\mathrm{R}$ & $\mathrm{R}$ & $\mathrm{R}$ & $\mathrm{R}$ & $\mathrm{S}$ & $\mathrm{R}$ & $\mathrm{R}$ & $\mathrm{R}$ & $\mathrm{R}$ & $\mathrm{R}$ & $\mathrm{R}$ & $\mathrm{R}$ & $\mathrm{R}$ & $\mathrm{R}$ & $\mathrm{R}$ & $\mathrm{R}$ & $\mathrm{R}$ & $\mathrm{R}$ & $\mathrm{R}$ & $\mathrm{R}$ & $\mathrm{R}$ & $\mathrm{R}$ & $\mathrm{S}$ & $\mathrm{R}$ & $\mathrm{R}$ & $\mathrm{R}$ & $\mathrm{R}$ \\
\hline NMRIL-H & $S^{d}$ & $\mathrm{R}$ & $\mathrm{R}$ & $\mathrm{R}$ & $\mathrm{R}$ & $\mathrm{R}$ & $\mathrm{R}$ & $\mathrm{R}$ & $\mathrm{R}$ & $\mathrm{S}$ & $\mathrm{R}$ & $\mathrm{R}$ & $\mathrm{R}$ & $\mathrm{R}$ & $\mathrm{R}$ & $\mathrm{S}$ & $\mathrm{R}$ & $\mathrm{R}$ & $\mathrm{S}$ & $\mathrm{R}$ & $\mathrm{R}$ & $\mathrm{R}$ & $\mathrm{R}$ & $\mathrm{R}$ & $\mathrm{R}$ & $\mathrm{R}$ & $\mathrm{R}$ \\
\hline NMRIL-N & $\mathrm{S}$ & $\mathrm{R}$ & $\mathrm{R}$ & $\mathrm{R}$ & $\mathrm{R}$ & $\mathrm{R}$ & $\mathrm{R}$ & $\mathrm{R}$ & $\mathrm{S}$ & $\mathrm{R}$ & $\mathrm{R}$ & $\mathrm{S}$ & $\mathrm{R}$ & $\mathrm{R}$ & $\mathrm{R}$ & $\mathrm{S}$ & $\mathrm{R}$ & $\mathrm{R}$ & $\mathrm{R}$ & $\mathrm{R}$ & $\mathrm{R}$ & $\mathrm{R}$ & $\mathrm{R}$ & $\mathrm{R}$ & $\mathrm{R}$ & $\mathrm{R}$ & $\mathrm{R}$ \\
\hline NMRIL-X & $\mathrm{R}$ & $\mathrm{R}$ & S & $\mathrm{R}$ & $\mathrm{R}$ & $\mathrm{R}$ & $\mathrm{S}$ & S & $\mathrm{R}$ & $\mathrm{R}$ & $\mathrm{S}$ & $\mathrm{R}$ & $\mathrm{R}$ & $\mathrm{R}$ & $\mathrm{R}$ & $\mathrm{R}$ & $\mathrm{R}$ & $\mathrm{R}$ & $\mathrm{R}$ & $\mathrm{R}$ & $\mathrm{R}$ & $\mathrm{R}$ & $\mathrm{R}$ & $\mathrm{R}$ & $\mathrm{R}$ & $\mathrm{R}$ & $\mathrm{R}$ \\
\hline NMRIL-AE & $\mathrm{S}$ & $\mathrm{S}$ & $\mathrm{R}$ & $\mathrm{R}$ & $\mathrm{S}$ & $\mathrm{R}$ & $\mathrm{R}$ & $\mathrm{R}$ & $\mathrm{S}$ & $\mathrm{R}$ & $\mathrm{R}$ & $\mathrm{R}$ & $\mathrm{R}$ & $\mathrm{R}$ & $\mathrm{R}$ & $\mathrm{R}$ & $\mathrm{R}$ & $\mathrm{R}$ & $\mathrm{R}$ & $\mathrm{R}$ & $\mathrm{R}$ & $\mathrm{R}$ & $\mathrm{R}$ & $\mathrm{R}$ & $\mathrm{S}$ & $\mathrm{R}$ & $\mathrm{R}$ \\
\hline NMRIL-F & $\mathrm{R}$ & $\mathrm{S}$ & $\mathrm{R}$ & $\mathrm{S}$ & $\mathrm{S}$ & $\mathrm{S}$ & $\mathrm{S}$ & $\mathrm{R}$ & $\mathrm{R}$ & $\mathrm{R}$ & $\mathrm{R}$ & $\mathrm{R}$ & $\mathrm{S}$ & $\mathrm{S}$ & $\mathrm{R}$ & $\mathrm{R}$ & $\mathrm{R}$ & $\mathrm{S}$ & $\mathrm{S}$ & $\mathrm{R}$ & $\mathrm{S}$ & $\mathrm{S}$ & $\mathrm{R}$ & $\mathrm{R}$ & $\mathrm{R}$ & $\mathrm{R}$ & $\mathrm{R}$ \\
\hline NMRIL-B & $\mathrm{S}$ & $\mathrm{S}$ & $\mathrm{S}$ & $\mathrm{R}$ & $\mathrm{S}$ & $\mathrm{S}$ & $\mathrm{S}$ & S & $\mathrm{R}$ & $\mathrm{S}$ & $\mathrm{S}$ & $\mathrm{R}$ & $\mathrm{R}$ & $\mathrm{R}$ & $\mathrm{R}$ & $\mathrm{R}$ & $\mathrm{S}$ & $\mathrm{R}$ & $\mathrm{R}$ & $\mathrm{R}$ & $\mathrm{R}$ & $\mathrm{R}$ & $\mathrm{S}$ & $\mathrm{R}$ & $\mathrm{S}$ & $\mathrm{R}$ & $\mathrm{R}$ \\
\hline NMRIL-Z & $\mathrm{S}$ & $\mathrm{R}$ & $\mathrm{S}$ & $\mathrm{S}$ & $\mathrm{S}$ & $\mathrm{S}$ & $\mathrm{R}$ & $\mathrm{S}$ & $\mathrm{S}$ & $\mathrm{S}$ & $\mathrm{S}$ & $\mathrm{R}$ & $\mathrm{R}$ & $\mathrm{R}$ & $\mathrm{S}$ & $\mathrm{S}$ & $\mathrm{R}$ & $\mathrm{R}$ & $\mathrm{R}$ & $\mathrm{S}$ & $\mathrm{R}$ & $\mathrm{S}$ & $\mathrm{R}$ & $\mathrm{R}$ & $\mathrm{R}$ & $\mathrm{R}$ & $\mathrm{R}$ \\
\hline NMRIL-E & $\mathrm{S}$ & $\mathrm{S}$ & $\mathrm{S}$ & $\mathrm{S}$ & $\mathrm{R}$ & $\mathrm{S}$ & $\mathrm{R}$ & $\mathrm{R}$ & $\mathrm{S}$ & $\mathrm{R}$ & $\mathrm{S}$ & $\mathrm{S}$ & $\mathrm{S}$ & $\mathrm{S}$ & $\mathrm{S}$ & $\mathrm{R}$ & $\mathrm{R}$ & $\mathrm{S}$ & $\mathrm{R}$ & $\mathrm{R}$ & $\mathrm{R}$ & $\mathrm{S}$ & $\mathrm{R}$ & $\mathrm{R}$ & $\mathrm{S}$ & $\mathrm{R}$ & $\mathrm{R}$ \\
\hline NMRIL-I & $\mathrm{S}$ & $\mathrm{S}$ & $\mathrm{S}$ & $\mathrm{S}$ & $\mathrm{R}$ & $\mathrm{S}$ & $\mathrm{S}$ & $\mathrm{S}$ & $\mathrm{S}$ & $\mathrm{S}$ & $\mathrm{R}$ & $\mathrm{S}$ & $\mathrm{S}$ & $\mathrm{R}$ & $\mathrm{R}$ & $\mathrm{R}$ & $\mathrm{S}$ & $\mathrm{R}$ & $\mathrm{S}$ & $\mathrm{R}$ & $\mathrm{R}$ & $\mathrm{R}$ & $\mathrm{S}$ & $\mathrm{R}$ & $\mathrm{R}$ & $\mathrm{R}$ & $\mathrm{R}$ \\
\hline NMRIL-G & $\mathrm{S}$ & $\mathrm{S}$ & S & $\mathrm{S}$ & $\mathrm{S}$ & $\mathrm{R}$ & $\mathrm{S}$ & S & $\mathrm{R}$ & $\mathrm{R}$ & $\mathrm{S}$ & $\mathrm{S}$ & $\mathrm{S}$ & $\mathrm{S}$ & $\mathrm{S}$ & $\mathrm{R}$ & $\mathrm{S}$ & $\mathrm{R}$ & $\mathrm{S}$ & $\mathrm{S}$ & $\mathrm{R}$ & $\mathrm{R}$ & $\mathrm{R}$ & $\mathrm{R}$ & $\mathrm{R}$ & $\mathrm{R}$ & $\mathrm{R}$ \\
\hline NMRIL-AA & $\mathrm{S}$ & $\mathrm{S}$ & $\mathrm{S}$ & $\mathrm{S}$ & $\mathrm{S}$ & $\mathrm{S}$ & $\mathrm{S}$ & S & $\mathrm{S}$ & $\mathrm{S}$ & $\mathrm{S}$ & $\mathrm{S}$ & $\mathrm{S}$ & $\mathrm{R}$ & $\mathrm{S}$ & $\mathrm{R}$ & $\mathrm{S}$ & $\mathrm{R}$ & $\mathrm{R}$ & $\mathrm{R}$ & $\mathrm{S}$ & $\mathrm{R}$ & $\mathrm{R}$ & $\mathrm{R}$ & $\mathrm{R}$ & $\mathrm{R}$ & $\mathrm{S}$ \\
\hline NMRIL-AD & $\mathrm{S}$ & $\mathrm{S}$ & $\mathrm{S}$ & $\mathrm{S}$ & $\mathrm{S}$ & $\mathrm{S}$ & $\mathrm{S}$ & $\mathrm{S}$ & $\mathrm{S}$ & $\mathrm{S}$ & $S$ & $\mathrm{R}$ & $\mathrm{S}$ & $\mathrm{S}$ & $\mathrm{S}$ & $\mathrm{R}$ & $\mathrm{R}$ & $\mathrm{R}$ & $\mathrm{R}$ & $\mathrm{R}$ & $\mathrm{S}$ & $\mathrm{R}$ & $\mathrm{S}$ & $\mathrm{R}$ & $\mathrm{R}$ & $\mathrm{R}$ & $\mathrm{S}$ \\
\hline NMRIL-M & $\mathrm{S}$ & $\mathrm{S}$ & $\mathrm{S}$ & $\mathrm{S}$ & $\mathrm{S}$ & $\mathrm{S}$ & $\mathrm{S}$ & $\mathrm{S}$ & $\mathrm{R}$ & $\mathrm{S}$ & $\mathrm{S}$ & $\mathrm{S}$ & $\mathrm{S}$ & $\mathrm{S}$ & $\mathrm{S}$ & $\mathrm{S}$ & $\mathrm{R}$ & $\mathrm{S}$ & $\mathrm{R}$ & $\mathrm{S}$ & $\mathrm{R}$ & $\mathrm{R}$ & $\mathrm{R}$ & $\mathrm{R}$ & $\mathrm{R}$ & $\mathrm{S}$ & $\mathrm{R}$ \\
\hline NMRIL-A & $\mathrm{S}$ & $\mathrm{S}$ & $\mathrm{S}$ & $\mathrm{S}$ & $\mathrm{S}$ & $\mathrm{S}$ & $\mathrm{S}$ & $\mathrm{S}$ & $\mathrm{S}$ & $\mathrm{S}$ & $\mathrm{R}$ & $S$ & $\mathrm{R}$ & $\mathrm{S}$ & $\mathrm{S}$ & $\mathrm{S}$ & $\mathrm{R}$ & $\mathrm{S}$ & $\mathrm{S}$ & $\mathrm{S}$ & $\mathrm{S}$ & $\mathrm{S}$ & $\mathrm{S}$ & $\mathrm{S}$ & $\mathrm{R}$ & $\mathrm{R}$ & $\mathrm{R}$ \\
\hline NMRIL-R & $\mathrm{S}$ & $\mathrm{S}$ & $\mathrm{S}$ & $\mathrm{S}$ & $\mathrm{S}$ & $\mathrm{S}$ & $\mathrm{S}$ & S & $\mathrm{S}$ & $\mathrm{S}$ & $\mathrm{S}$ & $\mathrm{S}$ & $\mathrm{S}$ & $\mathrm{S}$ & $\mathrm{S}$ & $\mathrm{S}$ & $\mathrm{S}$ & $\mathrm{S}$ & $\mathrm{S}$ & $\mathrm{R}$ & $\mathrm{R}$ & $\mathrm{S}$ & $\mathrm{R}$ & $\mathrm{S}$ & $\mathrm{R}$ & $\mathrm{R}$ & $\mathrm{R}$ \\
\hline NMRIL-S & $\mathrm{S}$ & $\mathrm{S}$ & $\mathrm{S}$ & $\mathrm{S}$ & $\mathrm{S}$ & $\mathrm{S}$ & $\mathrm{S}$ & $\mathrm{S}$ & $\mathrm{S}$ & $\mathrm{S}$ & $\mathrm{S}$ & $\mathrm{S}$ & $\mathrm{S}$ & $\mathrm{S}$ & $\mathrm{R}$ & $\mathrm{S}$ & $\mathrm{S}$ & $\mathrm{S}$ & $\mathrm{R}$ & $\mathrm{S}$ & $\mathrm{S}$ & $\mathrm{R}$ & $\mathrm{R}$ & $\mathrm{S}$ & $\mathrm{R}$ & $\mathrm{S}$ & $\mathrm{R}$ \\
\hline NMCA10399e & S & $\mathrm{S}$ & $\mathrm{S}$ & S & S & $\mathrm{S}$ & $\mathrm{S}$ & S & S & S & $\mathrm{S}$ & S & $\mathrm{S}$ & $\mathrm{S}$ & $\mathrm{S}$ & $\mathrm{S}$ & $\mathrm{S}$ & $\mathrm{S}$ & $\mathrm{S}$ & $\mathrm{S}$ & $\mathrm{S}$ & S & S & $\mathrm{S}$ & $\mathrm{S}$ & $\mathrm{S}$ & $\mathrm{S}$ \\
\hline
\end{tabular}

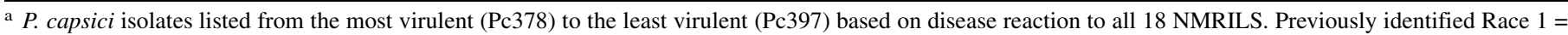
Pc1E8, Race $2=$ Pc33, and Race $3=$ Pc134 (Black 1999)

b Criollo de Morelos-334: negative control.

c Resistant phenotype: no lesions on roots and an average rating of $<1$.

d Susceptible phenotype: ranging from small lesions to death of plants and an average rating of $>1$.

e New Mexico Capsicum Accession 10399: positive control.

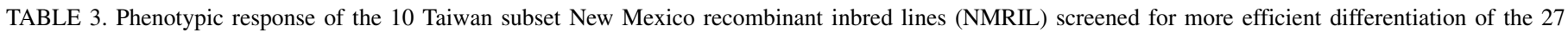
Phytophthora capsici isolates collected in Taiwan

\begin{tabular}{|c|c|c|c|c|c|c|c|c|c|c|c|c|c|c|c|c|c|c|c|c|c|c|c|c|c|c|c|}
\hline Cluster $^{\mathrm{a}}$ & 1 & 1 & 1 & 1 & 1 & 1 & 1 & 1 & 1 & 1 & 1 & 1 & 1 & 2 & 2 & 2 & 2 & 2 & 2 & 2 & 2 & 2 & 2 & 2 & 2 & 2 & 2 \\
\hline & \multicolumn{27}{|c|}{ Isolate $^{\mathrm{b}}$} \\
\hline Accession $^{c}$ & 378 & 374 & 376 & 134 & 33 & 379 & 383 & 380 & 377 & 381 & 398 & 385 & 375 & 393 & 395 & 384 & 373 & 389 & $1 \mathrm{E} 8$ & 382 & 396 & 388 & 413 & 391 & 390 & 397 & 392 \\
\hline NMRIL-AE & $S^{d}$ & $\mathrm{~S}$ & $\mathrm{R}$ & $\mathrm{R}$ & $\mathrm{R}$ & S & $\mathrm{R}$ & $\mathrm{R}$ & $\mathrm{R}$ & $\mathrm{R}$ & $\mathrm{R}$ & $\mathrm{R}$ & $S$ & $\mathrm{R}$ & $\mathrm{R}$ & $\mathrm{R}$ & $\mathrm{R}$ & $\mathrm{R}$ & $\mathrm{R}$ & $\mathrm{R}$ & $\mathrm{R}$ & $\mathrm{R}$ & S & $\mathrm{R}$ & $\mathrm{R}$ & $\mathrm{R}$ & $\mathrm{R}$ \\
\hline NMRIL-F & $\mathrm{R}^{\mathrm{e}}$ & $\mathrm{S}$ & $\mathrm{R}$ & $\mathrm{S}$ & $\mathrm{S}$ & $S$ & $\mathrm{R}$ & $\mathrm{R}$ & $\mathrm{S}$ & $\mathrm{S}$ & $\mathrm{R}$ & $\mathrm{R}$ & $\mathrm{R}$ & $\mathrm{R}$ & $\mathrm{R}$ & $\mathrm{R}$ & $\mathrm{S}$ & $\mathrm{S}$ & $\mathrm{R}$ & S & $\mathrm{S}$ & $\mathrm{S}$ & $\mathrm{R}$ & $\mathrm{R}$ & $\mathrm{R}$ & $\mathrm{R}$ & $\mathrm{R}$ \\
\hline NMRIL-B & $\mathrm{S}$ & $\mathrm{S}$ & $\mathrm{S}$ & $\mathrm{R}$ & $\mathrm{S}$ & $S$ & S & S & $\mathrm{R}$ & $\mathrm{S}$ & $\mathrm{R}$ & $\mathrm{S}$ & $\mathrm{R}$ & $\mathrm{R}$ & $\mathrm{S}$ & $\mathrm{R}$ & $\mathrm{R}$ & $\mathrm{R}$ & $\mathrm{R}$ & $\mathrm{R}$ & $\mathrm{R}$ & $\mathrm{R}$ & $\mathrm{S}$ & $\mathrm{S}$ & $\mathrm{R}$ & $\mathrm{R}$ & $\mathrm{R}$ \\
\hline NMRIL-Z & $\mathrm{S}$ & $\mathrm{R}$ & $\mathrm{S}$ & $\mathrm{S}$ & $\mathrm{S}$ & $S$ & $S$ & S & $\mathrm{R}$ & $\mathrm{R}$ & $\mathrm{R}$ & $\mathrm{S}$ & $\mathrm{S}$ & $\mathrm{S}$ & $\mathrm{R}$ & $\mathrm{S}$ & $\mathrm{R}$ & $\mathrm{R}$ & $\mathrm{S}$ & $\mathrm{R}$ & $\mathrm{R}$ & S & $\mathrm{R}$ & $\mathrm{R}$ & $\mathrm{R}$ & $\mathrm{R}$ & $\mathrm{R}$ \\
\hline NMRIL-E & $\mathrm{S}$ & $\mathrm{S}$ & $\mathrm{S}$ & $\mathrm{S}$ & $\mathrm{S}$ & $\mathrm{R}$ & $\mathrm{R}$ & S & S & $\mathrm{R}$ & $\mathrm{S}$ & $\mathrm{R}$ & $\mathrm{S}$ & $\mathrm{S}$ & $\mathrm{R}$ & $\mathrm{R}$ & S & $\mathrm{S}$ & $\mathrm{R}$ & $\mathrm{R}$ & $\mathrm{R}$ & S & $\mathrm{S}$ & $\mathrm{R}$ & $\mathrm{R}$ & $\mathrm{R}$ & $\mathrm{R}$ \\
\hline NMRIL-I & $\mathrm{S}$ & $\mathrm{S}$ & $\mathrm{S}$ & $\mathrm{S}$ & $\mathrm{S}$ & $\mathrm{R}$ & S & $\mathrm{R}$ & S & $\mathrm{S}$ & $\mathrm{S}$ & $\mathrm{S}$ & $\mathrm{S}$ & $\mathrm{R}$ & $\mathrm{S}$ & $\mathrm{R}$ & $\mathrm{R}$ & $\mathrm{R}$ & $\mathrm{R}$ & S & $\mathrm{R}$ & $\mathrm{R}$ & $\mathrm{R}$ & S & $\mathrm{R}$ & $\mathrm{R}$ & $\mathrm{R}$ \\
\hline NMRIL-G & $\mathrm{S}$ & $\mathrm{S}$ & $\mathrm{S}$ & $\mathrm{S}$ & $\mathrm{R}$ & S & S & S & S & $\mathrm{S}$ & $\mathrm{S}$ & $\mathrm{R}$ & $\mathrm{R}$ & $\mathrm{S}$ & $\mathrm{S}$ & $\mathrm{S}$ & $\mathrm{S}$ & $\mathrm{R}$ & $\mathrm{R}$ & S & $\mathrm{R}$ & $\mathrm{R}$ & $\mathrm{R}$ & $\mathrm{R}$ & $\mathrm{R}$ & $\mathrm{R}$ & $\mathrm{R}$ \\
\hline NMRIL-AA & $\mathrm{S}$ & $\mathrm{S}$ & $\mathrm{S}$ & $\mathrm{S}$ & $\mathrm{S}$ & S & S & S & S & $\mathrm{S}$ & $\mathrm{S}$ & $\mathrm{S}$ & $\mathrm{S}$ & $\mathrm{S}$ & $\mathrm{S}$ & $\mathrm{R}$ & $\mathrm{R}$ & $\mathrm{R}$ & $\mathrm{R}$ & $\mathrm{R}$ & S & $\mathrm{R}$ & $\mathrm{R}$ & $\mathrm{R}$ & $\mathrm{R}$ & $\mathrm{S}$ & $\mathrm{R}$ \\
\hline NMRIL-M & $\mathrm{S}$ & $\mathrm{S}$ & $\mathrm{S}$ & $\mathrm{S}$ & $\mathrm{S}$ & S & S & S & S & $\mathrm{S}$ & $\mathrm{S}$ & $\mathrm{S}$ & $\mathrm{R}$ & $\mathrm{S}$ & $\mathrm{R}$ & $\mathrm{S}$ & S & S & $\mathrm{S}$ & $\mathrm{R}$ & $\mathrm{R}$ & $\mathrm{R}$ & $\mathrm{R}$ & $\mathrm{R}$ & S & $\mathrm{R}$ & $\mathrm{R}$ \\
\hline NMRIL-S & $\mathrm{S}$ & $\mathrm{S}$ & $\mathrm{S}$ & $S$ & $\mathrm{~S}$ & $S$ & $S$ & $S$ & S & $\mathrm{S}$ & $\mathrm{S}$ & $\mathrm{S}$ & $\mathrm{S}$ & $\mathrm{S}$ & $\mathrm{S}$ & $\mathrm{S}$ & $\mathrm{R}$ & $\mathrm{S}$ & $\mathrm{S}$ & $\mathrm{R}$ & $S$ & $\mathrm{R}$ & $\mathrm{R}$ & $\mathrm{R}$ & $\mathrm{S}$ & $\mathrm{R}$ & $\mathrm{S}$ \\
\hline
\end{tabular}

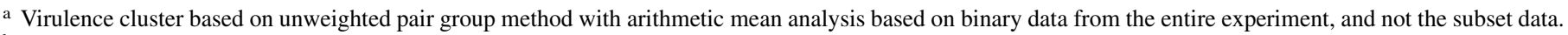

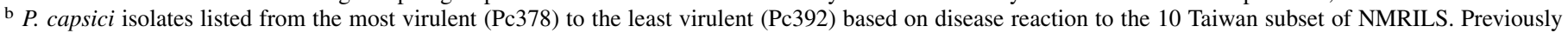
identified race $1=\mathrm{Pc} 1 \mathrm{E} 8$, race $2=\mathrm{Pc} 33$, and race $3=$ Pc134 (Black 1999).

c Taiwan subset of NMRILs listed from most resistant (NMRIL-AE) to least (NMRIL-S).

d Susceptible phenotype: ranging from small lesions to death of plants and an average rating of $>1$.

e Resistant phenotype: no lesions on roots and an average rating of $<1$. 
distribution of mating type varies around the world (Castro-Rocha et al. 2016; da Costa Ribeiro and Bosland 2012; Glosier et al. 2008; Hu et al. 2013; Sun et al. 2008; Sy et al. 2008). It is possible that mating type distributions outside of the expected ratio of $1: 1$ in a given region or country could be due to insufficient sampling. However, asexual reproduction has been found to increase the prevalence of a particular mating type (Barchenger et al. 2017; Carlson et al. 2017).

Despite the high proportion of the A 2 mating type, each isolate in our study was a different race, including those collected in the same field, which supports the findings of Jiang et al. (2015) who identified multiple races in the same field in the United States. Interestingly, the mode of reproduction for P. capsici in Taiwan has been found to be largely asexual or clonal and there is a relatively narrow genetic base for populations on the island (Barchenger et al. 2017). However, rapid genetic changes due to random mutation at virulence loci have been observed in P. infestans and P. sojae (Drenth et al. 1994, 1996; Förster et al. 1994; Goodwin et al. 1995). Therefore, the multiple races identified in a single field might be the result of random mutation and not genetic recombination. The identification of multiple races in a single field has important implications for anticipatory breeding efforts, because cultivars with resistance to any given race may or may not be resistant to a different race in the same production field.

This research and the work done by da Costa Ribeiro and Bosland (2012) demonstrate that NMRILs provide a system for race characterization on a global scale through the unique pattern of disease reactions across the lines (Supplementary Table S1). The phenotypic data collected through screening isolates using the NMRILs allows for a standardized virulence phenotype to be universally used to describe the races of $P$. capsici. Detection of new races as well as regularly monitoring of the race structure using a universal system is an important component of anticipatory breeding. Additionally, the NMRILs can serve as new sources of resistance, as a resistant reaction would indicate a race specific reaction in a given region. The NMRILs are useful for anticipatory breeding for resistance on a more local scale. The two virulence clusters identified in the Eastern and Central regions of Taiwan allow pepper breeders to focus their efforts and release cultivars regionally or temporally. Additionally, isolates from Yunlin County (Central region) were exclusively in Cluster 1, while isolates from Taitung County (Eastern region) were exclusively in Cluster 2, which has relevance for local deployment of resistant cultivars. Taiwan is an island with a large mountain range separating the Eastern and Central regions. This geographic separation could play a role in the development of the two virulence clusters, with the more virulent isolates in the Central region and less virulent isolates in the Eastern region. NMRIL-AE was resistant to every isolate in Cluster 2 and could be a useful source of resistance in this area. Conversely, none of the lines screened were resistant to every isolate in Cluster 1; however, NMRIL-AA and NMRIL-S were susceptible to every isolate in Cluster 1 and should not be included in breeding for resistance on the west coast of Taiwan. Additionally, we found that isolates that were isolated from root tissue were more virulent than stemisolated isolates, which could be due to the use of a root-rot assay in this experiment.

Breeding chile pepper cultivars with resistance to $P$. capsici is challenging, because most of the recently characterized isolates (Jiang et al. 2015) represent distinct virulence phenotypes when differentiated by the NMRILs. However, one major implication of this work is that it allows us to identify NMRILs, and potentially $R$ genes in the future, that are associated with broad spectrum resistance. When challenged by the Taiwanese isolates, NMRIL-P and NMRIL-O were identified as being resistant to most isolates and NMRIL-A, NMRIL-R, and NMRIL-S were resistant to the fewest isolates. This differs slightly from the findings of Sy et al. (2008) and Jiang et al. (2015) who found that while NMRIL-P was resistant to most of the isolates screened, NMRIL-O and NMRIL-A had moderate resistance, and NMRIL$\mathrm{R}$ and NMRIL-S were resistant to the fewest isolates. These differences illustrate that despite the global utility of the NMRILs, the genes required for resistance can vary by country or region. However, these results also identify NMRIL-P as having $R$ genes that are associated with resistance to $P$. capsici on multiple continents. These findings allow the breeder to target their efforts in $R$ gene discovery and molecular marker development to fewer resistance sources for wide applicability, while also being able to focus on country- or region-specific resistance sources. This tiered approach to resistance breeding could allow for better resistant cultivars deployment.

A major limitation of breeding for resistance to Phytophthora root rot is the lack of a universal race detection system. Race detection of $P$. capsici has been widely studied in New Mexico (Jiang et al. 2015; Monroy-Barbosa and Bosland 2011; Oelke et al. 2003; Sy et al. 2008), California (Glosier et al. 2008), and Brazil (da Costa Ribeiro and Bosland 2012); however, the host differential used and therefore the races identified differ around the world. For example, race 1 was used by Sy et al. (2008) to designate the most virulent race identified in their study, while race 1 was used at WorldVeg for their least virulent race (Black 1999). Although "race 1" has been used for both isolates of $P$. capsici, these races are almost certainly genetically divergent given they differed in disease reactions for NMRIL-A, -B, -E, -G, $-\mathrm{H},-\mathrm{I},-\mathrm{O},-\mathrm{Z}$, and -AA. Therefore, due to the numerous races and the different disease phases, we recommend that the term race be supplemented by the term "virulence phenotype," to designate the virulence of $P$. capsici isolates to the various host resistance genes. Races can be identified based on the differential reaction with the NMRILs, but there appears to be many races and the numbering system currently in place has no biological meaning. Designating the isolates by the resistance genes overcome by the pathogen in the host differential has more practical use. This investigation demonstrated that NMRILs are a valuable tool to assist scientists in working together on race identification and breeding for resistance to a serious and complex pathogen. The NMRILs subset will be useful to investigate the Capsicum-Phytophthora system in the regions of Asia where P. capsici is known to be a major production constraint of peppers. Therefore, the NMRILs can be adopted by plant pathologists and plant breeders globally to work together to limit worldwide losses due to this serious plant pathogen.

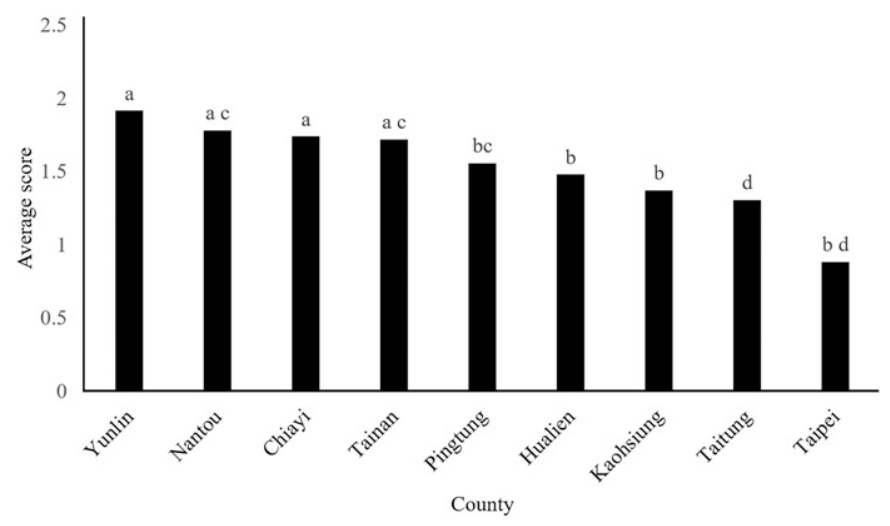

Fig. 2. Differences in average disease rating of isolates by the county they were collected in Taiwan. Each isolate was screened using the New Mexico recombinant inbred lines. Bars with different letters are significantly different at $P<0.05$ (Kruskal-Wallis and Dunn's Test). 


\section{ACKNOWLEDGMENTS}

We thank L. Black for his advice and helpful comments throughout this project, T. Berke for his guidance in the experimental design, and M. Mecozzi for her editorial oversight with the manuscript.

\section{LITERATURE CITED}

Ann, P. J., Wong, I. T., and Tsai, J. N. 2008. Appearance of A2 mating type of Phytophthora capsici in Taiwan. (Abstr.) Plant Pathol. Bull. 17:69.

Barchenger, D. W., Lamour, K. H., Sheu, Z. M., Shrestha, S., Kumar, S., Lin, S. W., Burlakoti, R., and Bosland, P. W. 2017. Intra- and intergenomic variation of ploidy and clonality characterize Phytophthora capsici on Capsicum sp. in Taiwan. Mycol. Prog. 16:955-963.

Black, L. L. 1999. Studies on Phytophthora blight in pepper. Pages 25-27 in: AVRDC Report 1998. N. S. Talekar, ed. Asian Vegetable Research and Development Center, Shanhua, Taiwan.

Black, L. L., and Berke, T. 1998. Breeding for Phytophthora resistance in pepper. Proc. Xth Eucarpia Meet Gene. Breed. Capsicum Eggplant 115119.

Bosland, P. W. 2008. Think global, breed local: Specificity and complexity of Phytophthora capsici. In: 19th International Pepper Conf. Atlantic City, NJ.

Bosland, P. W., and Lindsey, D. L. 1991. A seedling screen for Phytophthora root rot of pepper, Capsicum annuиm. Plant Dis. 75:1048-1050.

Boutemy, L. S., King, S. R. F., Win, J., Hughes, R. K., Clarke, T. A., Blumenschein, T. M. A., Kamoun, S., and Banfield, M. J. 2011. Structures of Phytophthora RXLR effector proteins a conserved but adaptable fold underpins functional diversity. J. Biol. Chem. 286:35834-35842.

Candole, B. L., Conner, P. J., McGregor, C., Waters, V., and Ji, P. 2012. The disease reactions of heirloom bell pepper 'California Wonder' to Phytophthora capsici. Agric. Sci. 3:417-424.

Carlson, M. O., Gazave, E., Gore, M. A., and Smart, C. D. 2017. Temporal genetic dynamics of an experimental, biparental field population of Phytophthora capsici. Front. Genet. 8:26.

Castro-Rocha, A., Shrestha, A., Lyon, B., Grimaldo-Pantoja, G. L., Flores-Marges, J. P., Valero-Galván, J., Aguirre-Ramíez, M., Osuna-Ávila, P., Gómez-Dorantes, N., Ávila-Quezada, G., de, J., Luna-Ruíz, J., Rodríguez-Alvarado, G., Fernández-Pavía, S. P., and Lamour, K. H. 2016. An initial assessment of the genetic diversity for Phytophthora capsici in northern and central Mexico. Mycol. Prog. 15:15.

Crosby, K. M. 2008. Peppers. Pages 221-248 in: Vegetables II. J. Prohens and F. Nuez, eds. Springer, New York.

da Costa Ribeiro, C. S., and Bosland, P. W. 2012. Physiological race characterization of Phytophthora capsici isolates from several host plant species in Brazil using New Mexico recombinant inbred lines of Capsicum аппиит at two inoculum levels. J. Am. Soc. Hortic. Sci. 137:421-426.

Drenth, A., Tas, I. C. Q., and Grovers, F. 1994. DNA fingerprinting uncovers a new sexually reproducing population of Phytophthora infestans in the Netherlands. Eur. J. Plant Pathol. 100:97-107.

Drenth, A., Whisson, S. C., Maclean, D. J., Irwin, J. A. G., Obst, N. R., and Ryley, M. J. 1996. The evolution of races of Phytophthora sojae in Australia. Phytopathology 86:163-169.

Dunn, A. R., Bruening, S. R., Grünwald, N. J., and Smart, C. D. 2014. Evolution of an experimental population of Phytophthora capsici in the field. Phytopathology 104:1107-1117.

Dunn, A. R., Milgroom, M. G., Meitz, J. C., McLeod, A., Fry, W. E., McGarth, M. T., Dillard, H. R., and Smart, C. D. 2010. Population structure and resistance to mefenoxam of Phytophthora capsici in New York State. Plant Dis. 94:1461-1468.

Erwin, D. C., and Riberio, O. K. 1996. Phytophthora Diseases Worldwide. American Phytopathological Society, St. Paul, MN.

Förster, H., Tyler, B. M., and Coffey, M. D. 1994. Phytophthora sojae races have arisen by clonal evolution and by rare outcrosses. Mol. Plant-Microbe Interact. 7:780-791.

Glosier, B. R., Ogundiwin, E. A., Sidhu, G. S., Sischo, D. R., and Prince, J. P. 2008. A differential series of pepper (Capsicum апnиит) lines delineates fourteen physiological races of Phytophthora capsici. Euphytica 162:23-30.

Gniffke, P. A., Shieh, S. C., Lin, S. W., Sheu, Z. M., Chen, J. R., Ho, F. I., Tsai, W. S., Chou, Y. Y., Wang, J. F., Cho, M. C., Schafleitner, R., Kenyon, L., Ebert, A. W., Srinivasan, R., and Kumar, S. 2013. Pepper research and breeding at AVRDC-The World Vegetable Center. Pages 305-311 in: Proc. XVth Eucarpia Meet. Gene. Breed. Capsicum Eggplant.

Gobena, D., Roig, J., Galmarini, C., Hulvey, J., and Lamour, K. H. 2012. Genetic diversity of Phytophthora capsici isolates from pepper and pumpkin in Argentina. Mycologia 104:102-107.

Goodwin, S. B., Sujkowski, L. S., and Fry, W. E. 1995. Rapid evolution of pathogenicity within clonal lineages of the potato late blight disease fungus. Phytopathology 85:669-676.
Granke, L. L., Quesada-Ocampo, L., Lamour, K. H., and Hausbeck, M. K. 2012. Advances in research on Phytophthora capsici on vegetable crops in the United States. Plant Dis. 96:1588-1600.

Hausbeck, M. K., and Lamour, K. H. 2004. Phytophthora capsici on vegetable crops: research progress and management challenges. Plant Dis. 88: 1292-1303.

Ho, W. C., and Ko, W. H. 1997. A simple method for obtaining single-spore isolates of fungi. Bot. Bull. Acad. Sin. 38:41-44.

Hu, J., Pang, Z., Bi, Y., Shao, J., Diao, Y., Guo, J., Liu, Y., Lv, H., Lumour, K. H., and Liu, X. 2013. Genetically diverse long-lived clonal lineages of Phytophthora capsici from pepper in Gansu, China. Phytopathology 103:920-926.

Hulvey, J., Hurtado-Gonzalez, O., Aragón-Caballero, L., Gobena, D., Storey, D., Finley, L., and Lamour, K. H. 2011. Genetic diversity of the pepper pathogen Phytophthora capsici on farms in the Amazonian high jungle of Peru. Am. J. Plant Sci. 2:461-466.

Hurtado-Gonzales, O., Aragon-Caballero, L., Apaza-Tapia, W., Donahoo, R., and Lamour, K. H. 2008. Survival and spread of Phytophthora capsici in Coastal Peru. Phytopathology 98:688-694.

Jiang, L., Sanogo, S., and Bosland, P. W. 2015. Using recombinant inbred lines to monitor changes in the race structure of Phytophthora capsici in chile pepper in New Mexico. Plant Health Prog. 16:235-240.

Lamour, K. H., and Hausbeck, M. K. 2001. The dynamics of mefenoxam insensitivity in recombining population of Phytophthora capsici characterized with amplified fragment length polymorphism markers. Phytopathology 91:553-557.

Lamour, K. H., and Hausbeck, M. K. 2002. The spatiotemporal genetic structure of Phytophthora capsici in Michigan and implication for disease management. Phytopathology 92:681-684.

Lamour, K. H., Mudge, J., Gobena, V., Hurtado-Gonzales, O. P., Schmutz, J., Juo, A., Miller, N. A., Rice, B. J., Raffaele, S., Cano, L. M., Bharti, A. K., Donahoo, R. S., Finley, S., Huitema, E., Hulvey, J., Platt, D., Salamov, A., Savidor, S., Sharma, R., Stam, R., Storey, D., Thines, M., Win, J., Haas, B. J., Dinwiddle, D. L., Jenkins, J., Knight, J. R., Affourtit, J. P., Han, C. S., Chertkov, O., Lindquist, E. A., Detter, C., Kamoun, I. V., and Kingsmore, S. F. 2012. Genome sequencing and mapping reveal loss of heterozygosity as a mechanism for rapid adaptation in the vegetable pathogen Phytophthora capsici. Mol. Plant-Microbe Interact. 25:1350-1360.

Leonian, L. H. 1922. Stem and fruit blight of peppers caused by Phytophthora capsici sp. nov. Phytopathology 12:401-408.

Lin, S. W., Chou, Y. Y., Shieh, H. C., Ebert, A. W., Kumar, S., Mavlyanova, R., Rouamba, A., Tenkouano, A., Afari-Sefa, V., and Gniffke, P. A. 2013. Pepper (Capsicum spp.) germplasm dissemination by AVRDC-The World Vegetable Center: An overview and introspection. Chron. Hortic. 53:21-27.

Lister, C., and Dean, C. 1993. Recombinant inbred lines for mapping RFLP and phenotypic markers in Arabidopsis thaliana. Plant J. 4:745-750.

McIntosh, R. A. 1992. Pre-emptive breeding to control wheat rusts. Euphytica 63:103-113.

McIntosh, R. A., and Brown, G. N. 1997. Anticipatory breeding for resistance to rust diseases in wheat. Annu. Rev. Phytopathol. 35:311-326.

Meitz, J. C., Linde, C. C., Thompson, A., Langenhoven, S., and McLeod, A. 2010. Phytophthora capsici on vegetable hosts in South Africa: Distribution, host range, and genetic diversity. Aus. Plant Pathol. 39:431-439.

Monroy-Barbosa, A., and Bosland, P. W. 2008. Genetic analysis of Phytophthora root rot race-specific resistance in chile pepper. J. Am. Hortic. Sci. 133:825-829.

Monroy-Barbosa, A., and Bosland, P. W. 2010. A rapid technique for multiplerace disease screening for phytophthora foliar blight on single Capsicum апnиит L. plants. HortScience 45:1563-1566.

Monroy-Barbosa, A., and Bosland, P. W. 2011. Identification of novel physiological races of Phytophthora capsici causing foliar blight using the New Mexico recombinant inbred lines set as a host differential. J. Am. Soc. Hortic. Sci. 136:205-210.

Naegele, R. P., Granke, L. L., Fry, J., Hill, T. A., Ashrafi, H., Van Deynze, A., and Hausbeck, M. K. 2017. Disease resistance to multiple fungal and oomycete pathogens evaluated using a recombinant inbred line population in pepper. Phytopathology 107:1522-1531.

Oelke, L. M., Steiner, R., and Bosland, P. W. 2003. Differentiation of race specific resistance to Phytophthora root rot and foliar blight in Capsicum аппиит. J. Am. Soc. Hortic. Sci. 128:213-218.

Quirin, E. A., Ogundiwin, E. A., Prince, J. P., Mazourek, M., Briggs, M. O., Chalanda, T. S., Kim, K. T., Falise, M., Kang, B. C., and Jahn, M. M. 2005. Development of sequence characterized amplified region (SCAR) primers for the detection of Phyto.5.2, a major QTL for resistance to Phytophthora capsici Leon. in pepper. Theor. Appl. Genet. 110:605-612.

Sanogo, S. 2003. Chile pepper and the threat of wilt diseases. Plant Health Progress doi.org/10.1094/PHP-2003-0430-01-RV.

Sanogo, S., and Ji, P. 2013. Water management in relation to control of Phytophthora capsici in vegetable crops. Agric. Water Manage. 129: 113-119. 
Shah, D. A., and Madden, L. V. 2004. Nonparametric analysis of ordinal data in designed factorial experiments. Phytopathology 94:33-43.

Sheu, Z. M., Chen, J. R., and Wang, T. C. 2009. First report of the A2 mating type of Phytophthora capsici infecting peppers (Capsicum annuum) in Taiwan. Plant Dis. 93:548.

Sheu, Z. M., Ho, F. I., Chen, Y. S., Wang, C. S., Wang, T. C., and Black, L. L. 2004. Characterization of Phytophthora capsici isolates associated with pepper Phytophthora blight in Taiwan. (Abstr.) Plant Pathol. Bull. 13:341.

Silvar, C., Duncan, J. M., Cooke, D. E. L., Williams, N. A., Díaz, J., and Merino, F. 2005. Development of specific PCR primers for identification and detection of Phytophthora capsici Leon. Eur. J. Plant Pathol. 112: 43-52.

Silvar, C., Merino, F., and Diaz, J. 2006. Diversity of Phytophthora capsici in northwest Spain: Analysis of virulence, metalaxyl response, and molecular characterization. Plant Dis. 90:1135-1142.

Stakman, E. C., Stewart, D. M., and Loegering, Q. W. 1962. Identification of physiologic races of Puccinia graminis var. tritici. U.S. Dep. Agric. ARS E-617.
Sun, W. X., Jia, Y. J., O’Neill, N. R., Feng, B. Z., and Zhang, X. G. 2008. Genetic diversity of Phytophthora capsici from eastern China. Can. J. Plant Pathol. 30:414-424.

Sy, O., Steiner, R., and Bosland, P. W. 2005. Inheritance of Phytophthora stem blight resistance as compared to Phytophthora root rot and Phytophthora foliar blight resistance in Capsicum annuum L. J. Am. Hortic. Soc. 130: 75-78.

Sy, O., Steiner, R., and Bosland, P. W. 2008. Recombinant inbred line differential identifies race-specific resistance to Phytophthora root rot in Capsicum annuum. Phytopathology 98:867-870.

Tuite, J. F. 1969. Plant Pathological Methods Fungi and Bacteria. Burgess Publishing Co., Minneapolis, MN.

Votava, E. J., and Bosland, P. W. 2002. A cultivar by any other name: Genetic variability in heirloom bell pepper 'California Wonder'. HortScience 37: 1100-1102.

Zhang, N., McCarthy, M. L., and Smart, C. D. 2008. A macroarray system for the detection of fungal and oomycete pathogens of solanaceous crops. Plant Dis. 92:953-960. 